\title{
The Functional Versatility of Transferrin Receptor 2 and Its Therapeutic Value
}

\author{
Antonella Roetto *, Mariarosa Mezzanotte and Rosa Maria Pellegrino \\ Department of Clinical and Biological Sciences, University of Torino, 10043 Orbassano, Torino, Italy; \\ mariarosa.mezzanotte@unito.it (M.M.); rosamaria.pellegrino@unito.it (R.M.P.) \\ * Correspondence: antonella.roetto@unito.it; Tel.: +39-011-6705462
}

Received: 28 September 2018; Accepted: 21 October 2018; Published: 23 October 2018

\begin{abstract}
Iron homeostasis is a tightly regulated process in all living organisms because this metal is essential for cellular metabolism, but could be extremely toxic when present in excess. In mammals, there is a complex pathway devoted to iron regulation, whose key protein is hepcidin (Hepc), which is a powerful iron absorption inhibitor mainly produced by the liver. Transferrin receptor 2 (Tfr2) is one of the hepcidin regulators, and mutations in TFR2 gene are responsible for type 3 hereditary hemochromatosis (HFE3), a genetically heterogeneous disease characterized by systemic iron overload. It has been recently pointed out that Hepc production and iron regulation could be exerted also in tissues other than liver, and that Tfr2 has an extrahepatic role in iron metabolism as well. This review summarizes all the most recent data on Tfr2 extrahepatic role, taking into account the putative distinct roles of the two main Tfr2 isoforms, Tfr $2 \alpha$ and Tfr $2 \beta$. Representing Hepc modulation an effective approach to correct iron balance impairment in common human diseases, and with Tfr2 being one of its regulators, it would be worthwhile to envisage Tfr2 as a therapeutic target.
\end{abstract}

Keywords: Tfr2; iron metabolism; hepcidin; erythropoiesis; SNC

\section{Tfr2 Gene and Proteins}

Tfr2 is a type II transmembrane glycoprotein, a member of the transferrin receptor family and homologous to Tfr1 [1].

It is encoded by TFR2, a 2471 bp long gene localized on the long arm of human chromosome 7 (7q22.1) that consists of 18 exons, and gives origin to two main variants regulated by different specific promoters: Tfr $2 \alpha$ and Tfr2 $\beta$ (Figure 1).

Tfr $2 \alpha$ results from the transcription of all exons, and is prevalently and highly expressed in hepatocytes and erythroid cell lines. Tfr2 $\alpha$ cDNA is $2.3 \mathrm{~kb}$ long (AF067864), and the Tfr2 $\alpha$ is a protein of about $89 \mathrm{kDa}$ encompassing 801 amino acids [2]. As Tfr1, Tfr $2 \alpha$ has a short cytoplasmic tail (aa 1-80) that contains a consensus sequence YQRV for endocytosis, a transmembrane domain (aa 81-104) with four cysteines (aa 89-98 and 108-111), involved in disulphide bonds, likely responsible for TFR2 homodimerization, and a large extracellular domain (aa 105-801) comprising a protease-associated domain and two RGD motifs that bind di-ferric Tf (Fe2Tf). Furthermore, an $\mathrm{N}$-terminal mitochondrial targeting sequence (MTS) has been found in Tfr2 intracellular domain [3]. In vitro analysis demonstrated that Tfr $2 \alpha$ on cell membranes can be shed and give origin to a soluble form, and that this process is inhibited by Fe2Tf [4]; however, this form could not be found in animal or human sera.

Tfr2 $\alpha$ transcription is upregulated in mouse embryonic fibroblast cells (NIH3T3) by erythroid GATA1, EKLF, and cEBP $/ \alpha$ transcriptional factors, while FOG1 seems to inhibit GATA1 enhancement [5]. Also, hepatic Hnf $4 \alpha$ stimulates Tfr $2 \alpha$ transcription, since it is significantly decreased 
in liver-specific HNF4 $\alpha$-null mice [6]. There is no Tfr2 $\alpha$ IRE/IRP-dependent post-transcriptional regulation [7], while the hepatic tetraspanin CD81 is able to interact with Tfr2 $\alpha$ and induce its degradation [8].

Tfr2 $\beta$ has an in-frame transcription start site in exon 4, so the Tfr2 $\beta$ cDNA (NM_001206855.1) transcript lacks exons $1-3$, and presents 142 additional untranslated base pairs at its $5^{\prime}$ end. Tfr $2 \beta$ is ubiquitously expressed at low level, and mostly expressed in spleen, heart, and brain. The resulting protein lacks the cytoplasmic and the transmembrane domain [2]. Since no signal peptide involved in the secretory pathway could be evidenced in Tfr $2 \beta$ isoform, it is supposed to be a cytosolic $60 \mathrm{kDa}$ protein identical to the Tfr $2 \alpha$ extracellular domain. At the moment, no transcriptional/translational regulatory pathway is known for Tfr2 $\beta$ isoform (Figure 1 ).

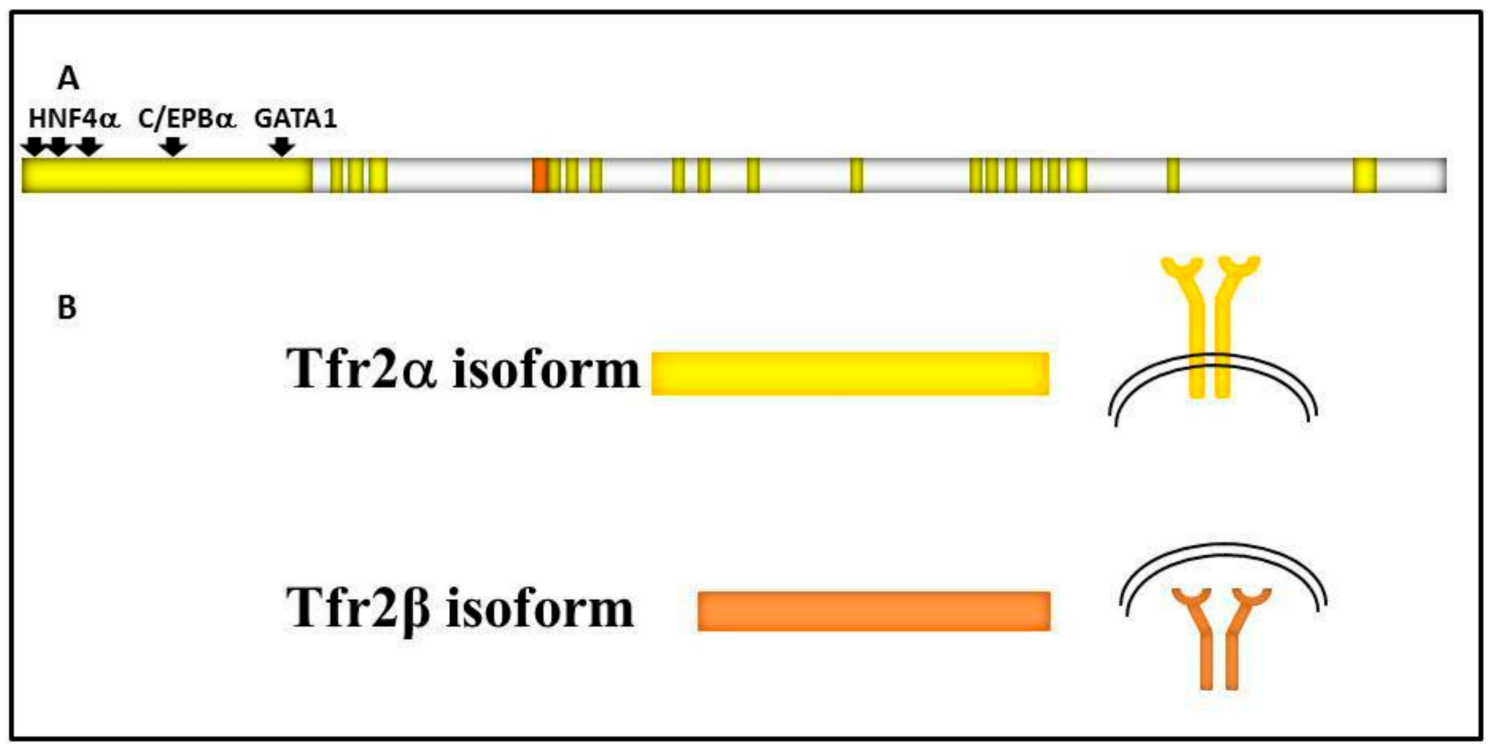

Figure 1. Schematic representation of: (A) TFR2 gene structure. TFR2 18 exons are in bright yellow, TFR $2 \alpha$ promoter is shown upstream of the gene, and transcriptional factors binding sites are highlighted by black arrows. $5^{\prime}$ untranslated region (142 bp long) of TFR $2 \beta$ transcript is shown in orange; (B) the two main transcripts and of Tfr $2 \alpha$ and Tfr $2 \beta$ isoforms, that are identical in the common sequence, and the two protein localizations, on the cell surface or in the cytosol, respectively.

\subsection{Tfr2 and HFE3}

Inactivating mutations of TFR2 gene (OMIM: 604720) lead to type 3 hereditary hemochromatosis (TFR2-HHC or HFE3), a rare recessive disorder characterized by increased transferrin saturation and serum ferritin concentration and iron overload [9].

HFE3 is one of the 5 different forms of hereditary hemochromatosis, a genetically heterogeneous disorder due to the deregulation of iron protein hepcidin (Hepc) [10] (Table 1). TFR2-HHC presents an earlier age of onset than type 1 hereditary hemochromatosis (HFE-HHC), and some pediatric patients have been reported so far. However, the majority of the affected individuals are young adults with abnormal serum iron indices [11].

Most of the mutations involved in HFE3 pathogenesis cause an inactivation of both Tfr2 isoforms, but some of them, occurring in exons from 1 to 3 , impair the production of the Tfr $2 \alpha$ isoform only [12-14]. Three patients with homozygote mutation M172K, that impairs Tfr2 $\beta$ translation initiation codon, were identified, all presenting typical hemochromatosis symptoms (cirrhosis, hypogonadism, cardiomyopathy, arthritis) at an average age of $38 \pm 5$ years [13,15].

Unfortunately, few clinical data are available on patients with these mutations to allow an exhaustive genotype/phenotype analysis. 
Table 1. Hereditary hemochromatosis (HHC types) and their relationship with hepcidin.

\begin{tabular}{cccccc}
\hline HH type & Acronym & Inheritance & Gene & Protein & Function \\
\hline HFE1 & HFE-HHC & AR & HFE & Hfe & Hepc regulator \\
HFE2a & HJV-HHC & AR & HJV & Hemojuvelin & Hepc regulator \\
HFE2b & HEPC-HHC & AR & HAMP & Hepc & Fe absorption inhibitor \\
HFE3 & TFR2-HHC & AR & TFR2 & Tfr2 & Hepc regulator \\
HFE4 & FPN1-HHC & AD & SLC40A1 & Fpn1 & Hepc receptor \\
\hline
\end{tabular}

\subsection{Systemic Iron Metabolism: The Hepc-Fpn1 Axis and the Proteins Involved in Hepc Regulation}

In mammals, the hepatocyte-secreted hormone Hepc regulates systemic iron homeostasis [16]. Hepc is codified by HAMP gene, which encodes for an 84 amino acids precursor protein, from which active 20-25 amino acids peptides are generated [17]. It is expressed primarily in the liver, although low levels of Hepc transcripts have been also reported in other organs [18].

How HAMP gene expression is regulated is mostly unknown. There are no IRE elements in its transcript, but the transcriptional factor CCAAT/enhancer binding protein- $\alpha$ is highly expressed in the liver, and seems to stimulate HAMP expression, while the hepatocyte nuclear factor $4-\alpha$ (HNF-4) represses Hepc expression [19].

The molecular processes involved in hepatic Hepc regulation are quite complex. Basal Hepc expression is regulated through the bone morphogenetic protein 6 (Bmp6) and Smad protein signaling pathway. In iron excess condition, Bmp6, produced and secreted by liver sinusoidal endothelial cells (LSECs) [20], binds to bone morphogenetic protein receptors, ALK2 and/or ALK3 [21], activin receptor type 2A (Actr2a) [22], Hemojuvelin (Hjv) and Neogenin [23]. The protein complex activates signals transducers Smad1/5/8, leading to their interaction with the common mediator Smad4. As a consequence of this interplay, Smad4 translocates into the nucleus and promotes Hepc transcription [16].

More recently, it has been demonstrated that bone morphogenetic protein 2 (Bmp2), expressed in LSECs, can also trigger Hepc transcription increase [24].

A second Hepc regulatory pathway involves di-ferric Tf (Fe2Tf) as the signaling of increased iron availability, transferrin receptor 1 (Tfr1), hemochromatosis type 1 protein (Hfe), and transferrin receptor 2 (Tfr2). It has been demonstrated that Fe2Tf competes with Hfe for binding Tfr1 then, when circulating, Fe2Tf increases as a consequence of iron raising, Hfe dissociates from Tfr1 and binds Tfr2 [25]. Hfe/Tfr2 complex is then responsible for Hepc response to iron increase, through the activation of Erk1/2 and MAPK cascade that has been proposed to potentially converge on the Bmps/Smad1/5/8-mediated pathway [26].

The hierarchy of the two pathway activations, and their relationship, are still not completely defined. In vitro data support the hypothesis that the complex Hfe/Tfr2 interacts with membrane $\mathrm{Hjv}(\mathrm{mHjv})$ on cell surface, thereby, the link between the two signaling pathways occurs [27]. It has been found, in vivo, that both Hfe and Tfr2 knock-out (KO) mice present lower pErk1/2 [28] and $\mathrm{pSmad} 1 / 5 / 8$ proteins $[29,30]$, meaning that these two proteins regulate both signal translation pathways. Hepatic Hepc upregulation is inhibited by matriptase 2 (MT-2 or Tmprss6), that acts as Hepc inhibitor cleaving mHjv expressed on the plasma membrane [31]. TMPRSS6 gene expression has been found to be induced by chronic dietary iron loading and Bmp6 injection [32], and its interaction with Neogenin facilitates mHjv cleavage and inactivation in transfected cells [23] (Figure 2).

On the contrary, in iron deficient conditions, this signaling pathway is inhibited by soluble $\mathrm{Hjv}$ (sHjv) and Tmprss6, which physically interacts with mHjv, causing its fragmentation.

Hepc expression in hepatocytes is systemically regulated by multiple signals: body iron availability, such as iron-loaded transferrin and hepatic iron stores, erythropoietic activity, hypoxia, and inflammation [33]. Hepc secreted by hepatocytes regulates iron release from duodenal enterocytes, splenic macrophages, and hepatocytes, which are responsible for dietary iron absorption, contain large amounts of iron from erythrocyte recycling, and act as an iron reservoir and export iron when 
needed, respectively. Hepc exerts its function, binding the iron exporter ferroportin 1 (Fpn1) [34] and stimulating complex internalization and degradation, leading, de facto, to cellular retention of iron [35]. Elevated plasma Hepc, as in inflammatory state, downregulates iron efflux from several cell types, and this leads to an overall reduction in plasma iron. On the contrary, low Hepc, as seen in iron-depleted or erythropoietic expansion conditions, causes an increased iron release by macrophages and by the basolateral site of villi duodenal cells.

A potent Hepc inhibitor signal is iron demand for erythropoiesis, mediated by three Hepc modulators (Gdf15, Twgs1, Erfe). Their roles and precise mechanisms in Hepc regulation are still not completely clear, but Erfe, in particular, has emerged as a potent Hepc negative regulator in conditions of acute erythropoietic demand, acting in conjunction with erythropoietin (Epo) signaling, as well as in anemia of inflammation (AI) condition [36].

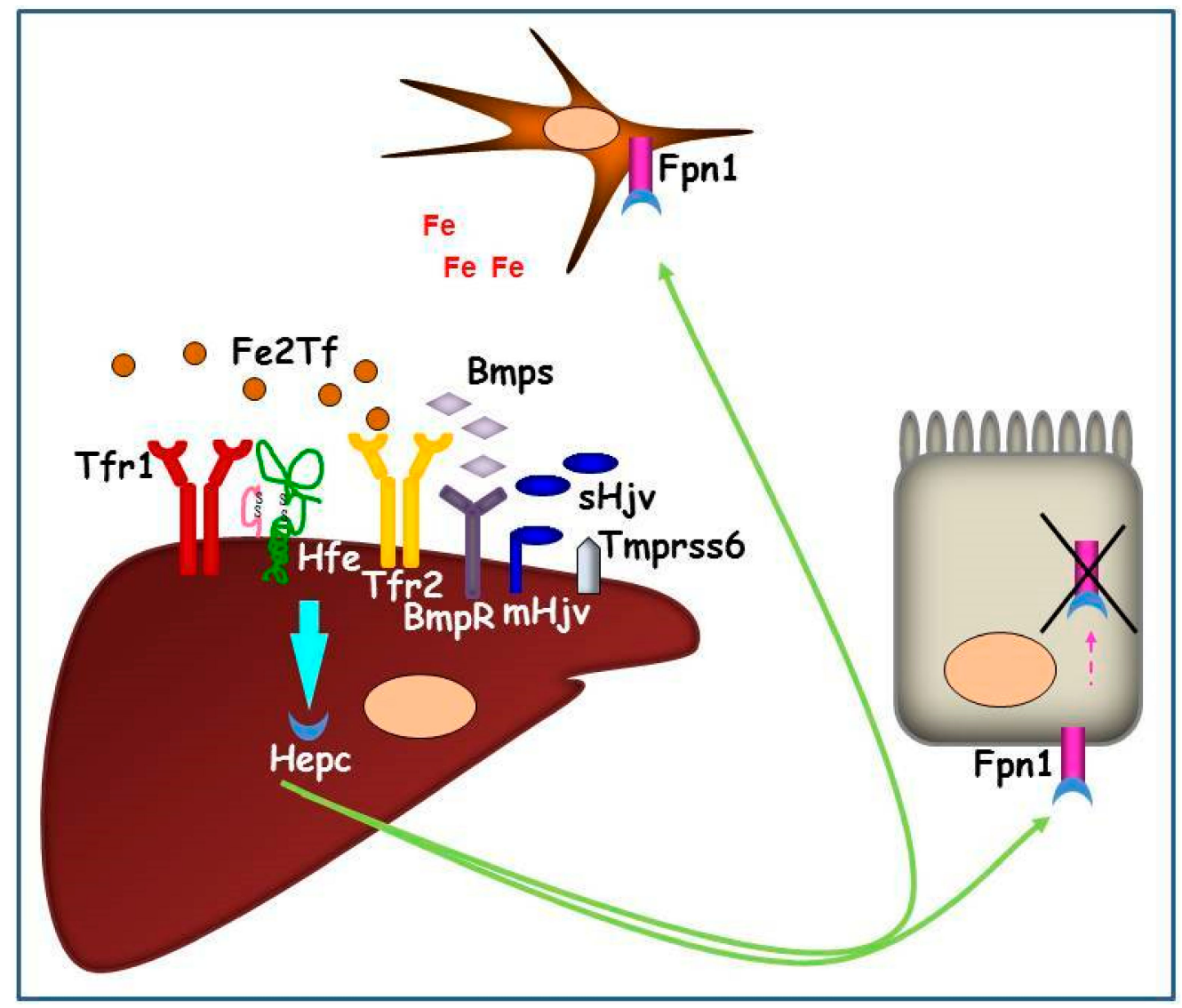

Figure 2. Graphic representation of the hepatic Hepc pathway in conditions of systemic iron increase. The iron signaling proteins (Fe2Tf and Bmps) interact with iron sensors (Tfr1, Hfe, Tfr2, BmpRs) and their co-activator (mHjv) to promote Hepc production. Hepc, secreted by hepatocytes, is transported in plasma and binds iron exporter Fpn1 on duodenal and reticuloendothelial cell surfaces causing its internalization and intracellular degradation. As a consequence, iron remains entrapped in these cells, systemically reducing the metal availability.

HAMP expression is induced by inflammation and infection. This acute phase response involves a different pathway from the ones described above, and is mainly mediated by interleukin 6 (IL-6) inflammatory cytokine, and requires the signal transducer and activator of transcription 3 (STAT3) activation, and the binding of STAT3 to a STAT3-binding motif in the Hepc promoter [37]. In addition, cytokine IL-22, involved in immunological response to extracellular infections, as well as Toll-like receptor 5 (TLR5) agonist flagellin, seem to upregulate Hepc, strengthening the hypothesis of a possible Hepc role in innate immunity [38]. 
Conversely, HAMP expression is repressed by hypoxia both in vitro and in vivo in animal models [33] and humans [39,40]. The mediator of Hepc response to hypoxia seems to be the hypoxia inducible factor (HIF), even though it is not clear if it acts directly or indirectly on Hepc regulation [16]. The fact that Hepc inhibitor, Tmprss6, presents a hypoxia responsive element (HRE) in its promoter [41] might make Tmprss6 the linking protein between hypoxia and iron homeostasis.

Mutations in HAMP gene and in genes codifying for Hepc regulatory proteins (HFE, TFR2, and $H J V)$ cause the lack of upregulation of Hepc as a response to increased liver iron stores. In fact, inappropriately low levels of liver Hepc are observed in patients and mouse models of hereditary hemochromatosis [42,43]. These conditions promote a continuous dietary iron absorption that leads to iron overload. On the contrary, inappropriately high Hepc has been found in animal models and patients with iron resistant iron deficient anemia (IRIDA), a genetic disorder due to mutations in TMPRSS6 gene [44-46].

Mutations in HAMP gene and in genes codifying for Hepc regulatory proteins (HFE, TFR2, and $H J V)$ cause the lack of upregulation of Hepc as a response to increased liver iron stores. In fact, inappropriately low levels of liver Hepc are observed in patients and mouse models of hereditary hemochromatosis [42,43]. These conditions promote a continuous dietary iron absorption that leads to iron overload. On the contrary, inappropriately high Hepc has been found in animal models and patients with iron resistant iron deficient anemia (IRIDA), a genetic disorder due to mutations in TMPRSS6 gene [44-46].

\section{Tfr2 in Liver}

In the liver, $\operatorname{Tfr} 2 \alpha$ is a sensor of circulating iron, but the knowledge about the Tfr $2 \alpha$ hepatic function is still incomplete. It is known that Tfr2 $\alpha$ localizes in caveolar microdomains [47], membrane structures involved in the recruitment of receptors that can be activated by ligand binding [48]. Also, Tfr $2 \alpha$ localizes in lipid raft domains on the exosomal cell membrane, where it is internalized by clathrin-mediated endocytosis, if transferrin saturation (TS) is low [49].

Tfr $2 \alpha$ protein regulation occurs mainly through its stabilization on the cell membrane as a consequence of the binding to Fe2Tf [50,51]. An in vitro study showed that, in the presence of Fe2Tf, Tfr $2 \alpha$ has an increased half-life and is recycled, while in presence of apo-Tf membrane, Tfr2 $\alpha$ is mainly subjected to lysosomal degradation [52]. It has been recently demonstrated that CD81 is also able to induce Tfr $2 \alpha$ degradation, but the correlation between this Tfr $2 \alpha$ regulatory route and Hepc pathway is still obscure [8].

Therefore, increased TS has an opposite effect on the two Tfrs via two different mechanisms: it causes a decrease of Tfr1, regulated by the IRE/IRP system, but a stabilization of Tfr $2 \alpha$ on the cell surface [1].

This supports the hypothesis that Tfr2 $\alpha$ exerts its function(s) as a signaling receptor more than as an iron importer.

According to the available in vitro data, hepatic Tfr2 $\alpha$ interacts, on the cell membrane, with two main iron proteins, Tfr1 and Hfe.

The current model assumes that Tfr $2 \alpha$, in conjunction with HFE and Tfr1, is a partner of a sensor complex of circulating iron that activates Hepc in response to elevated TS [53]. In physiological conditions (TS 30-35\%) Hfe and the complex Tf/Tfr1 are bound on the plasma cells; when TS increases in response to increased iron availability, loaded Tf impairs Hfe binding to Tfr1/Tf complex, leading it to bind $\operatorname{Tfr} 2 \alpha$, that is stabilized on the membrane by the same $\mathrm{Fe}^{2} \mathrm{Tf}$. The resulting complex Tfr2 $\alpha / \mathrm{Fe} 2 \mathrm{Tf} / \mathrm{Hfe}$ causes the activation of Hepc transcription [25]. On the HuH7 hepatoma cell surface, this Tfr $2 \alpha$ /HFE interaction occurs within a multiprotein complex, that also includes mHjv [27]. It remains to be demonstrated if this complex activates the intracellular signaling to upregulate Hepc expression, also, in vivo.

In the presence of Fe2Tf, Tfr2 $\alpha$ is able to activate Erk1/2 and p38 MAPK kinase signaling transduction pathway [47], since Tfr2 KO mice present a decrease of pErk1/2 [28]. Furthermore, 
the Smad1/5/8 pathway also seems to be involved in Tfr $2 \alpha$-mediated signal transduction, since $\mathrm{pSmad} 1 / 5 / 8$ is decreased in Tfr2 $\mathrm{KO}$ animals, as well [29].

Erk $1 / 2$ phosphorylation could be increased also by Hfe overexpression, and both Tfr 2 and Hfe cause an increase of the pro-hormone convertase furin [29], previously demonstrated to be involved in Hepc regulation [54]. Whether it is the sole and/or the main Tfr2 dependent Hepc regulatory pathway is still not clear.

\section{TFR2 Mouse Models}

The first Tfr2 $\mathrm{KO}$ animal model was generated by targeted mutagenesis, introducing a premature stop codon (Y245X) in the murine Tfr2 coding sequence [55]. This mutation is homologous to the Y250X variant, originally detected in humans and responsible for HFE3 [9]. Even young homozygous Y245X mice maintained on a standard diet had high liver iron concentration, in agreement with the observation of early iron overload in HFE3 patients [11]. As in humans, heterozygous animals were normal. The histological distribution of iron resembles the features of HFE3, with the typical liver periportal accumulation.

Subsequently, different murine models of Tfr2 inactivation were developed, including Tfr2 total (Tfr2 KO) and liver-specific (Tfr2 LCKO) knockouts [56,57] as well as a Tfr2/Hfe double KO [28]. All these models are characterized by an inadequate hepatic Hepc expression and liver iron overload with variable severity. However, when generated in the same genetic background, Tfr2 $\mathrm{KO}$ mice were shown to have a more severe iron overload than Hfe KO, although less severe than the Tfr $2 / \mathrm{Hfe}$ double $\mathrm{KO}$ [58]. These observations are in agreement with the model of Tfr2/Hfe proteins' cooperation in the liver.

In a double Tfr2/Hjv KO mouse model, plasma Hepc and Hepc transcription was lower than in Tfr2, and similar to Hjv single KOs, respectively. The same was true for the Tfr2/Hfe double $\mathrm{KO}$ [59]. Also, a recent study on a mouse model with inactivation of both Bmp6 and Tfr2 (Tfr2/Bmp6 double KO) demonstrated that loss of functional Tfr2 further represses Hamp expression, Smad5 phosphorylation, and plasma Hepc amount in Bmp6 KO mice. The same results were obtained in the Hfe/Bmp6 double KO, and the Hfe/Bmp6/Tfr2 triple KO [60]. All these data support the hypothesis that Tfr2 and Hfe act downstream Bmp6 and upstream Hjv in Hepc regulatory pathway.

Last, Tfr2 germinal vs liver-specific KO animals highlighted a distinct function of Tfr2 outside the liver in maintaining iron balance. In fact, Tfr2 $\mathrm{KO}$ mice have less severe iron overload, slightly higher hemoglobin $(\mathrm{Hb})$ levels $[57,61]$, and moderate macrocytosis than Tfr2 LCKO [56,57].

To study the specific function of Tfr $2 \beta$ isoform in iron metabolism, a specific mouse model was generated, introducing the M167K substitution in the Tfr2 protein [57]. This mutation, homologous to the one found in naturally mutant individuals with HFE3, substitutes the start codon methionine of the Tfr $2 \beta$ isoform, with a lysine. Interestingly, this knock-in mouse model (Tfr2 KI), specifically lacking the Tfr $2 \beta$-isoform $\left(\alpha^{+} \beta^{0}\right)$, is characterized by normal transferrin saturation, liver iron concentration, Hepc, and Bmp6 levels, but shows transient anemia at a young age. In addition, adult Tfr2 KI animals accumulate iron in the spleen, due to a significant reduction of iron exporter Fpn1 mRNA, thus suggesting a possible regulatory effect of Tfr $2 \beta$ isoform on splenic Fpn1 expression. These data are further supported by the results obtained in Tfr2 macrophage-specific KO mouse model. These animals present normal systemic iron parameters, but lower Fpn1 transcript and protein in peritoneal macrophages [62]. Recent studies demonstrated that Tfr $2 \beta$ is well expressed in reticuloendothelial cells of different tissues, where it exerts its role in modulating iron availability in these tissues, acting on Fpn1 transcription (see below). Since Fpn1 protein has several regulatory systems both at the transcriptional $[63,64]$ and post-transcriptional level through IRE/IRP system [7], and origins from different Fpn1 transcripts with or without IREs [65], it remains to be clarified how and when Tfr2 $\beta$ acts on Fpn1 regulation. 


\section{Tfr2 in Extrahepatic Tissues}

\subsection{Tfr2 in the Erythropoietic Compartment}

A Tfr $2 \alpha$ erythropoietic role was firstly hypothesized in genome-wide association studies that identified Tfr $2 \alpha$ polymorphisms affecting hematologic parameters $[66,67]$. These data were further strengthened by the identification of Tfr $2 \alpha$ as a component of the erythropoietin receptor (EpoR) complex in erythroid progenitor cells. Tfr $2 \alpha$ was shown to be crucial for efficient transport of EpoR to the cell surface and for its terminal differentiation, since human erythroid progenitors with silenced Tfr $2 \alpha$ showed a delayed differentiation [68]. Another hint was provided by the increased $\mathrm{Hb}$ content present only in Tfr2 germinal KO, but not in liver-specific KO mice. Since both mouse models manifest comparable iron overload, the lack of enhanced hemoglobinization in Tfr2 LCKO mice suggests that the erythroid function of Tfr2 $\alpha$ is preserved [68]. Also, double Tmprss6/Tfr2 KO mice develop erythrocytosis while, in double Tmprss6/Tfr2 LCKO mice, where Tfr2 $\alpha$ is functional in erythroid cells, red blood cells (RBC) number is normal [61].

Recently, a mouse model lacking Tfr2 in bone marrow cells (Tfr2 ${ }^{\mathrm{BMKO}}$ ) was developed injecting $\mathrm{BM}$ cells from Tfr2 $\mathrm{KO}$ mice in lethally irradiated C57/BL6 mice. Tfr2 ${ }^{\mathrm{BMKO}}$ mice manifest reduced mean corpuscular value (MCV) and low Hepc levels as a typical response to iron deficiency, but an enhanced terminal erythropoiesis, demonstrated by increased RBC and $\mathrm{Hb}$ content [69]. Interestingly, erythropoiesis and Epo level in these mice do not change in a mild dietary restriction setting, as happens for WT animals, where the Epo level is drastically increased.

As a whole, these data suggest that the lack of Tfr2 confers increased Epo sensitivity to erythroid progenitor cells, a hypothesis that is further supported by the induction of Epo target genes, like Hamp regulator Erfe [70], in these animals.

A similar animal model was recently developed crossing Tfr2 floxed mice with Vav-Cre expressing mice to obtain Tfr2 silencing in erythroid compartment [62]. Results differed from previous work since decreased RBC and splenomegaly were observed, but these discrepancies might be explained by the different procedures used to create the two mouse models since, in the first case, Tfr 2 is silenced in all bone marrow $(\mathrm{BM})$ cell lines after a BM transplant procedure while, in the latter, only the erythroid cell lines are Tfr2 null.

In another study, Tfr2 erythropoietic role was further investigated studying the erythropoiesis of two Tfr2 mice with one or both Tfr2 isoforms silenced (Tfr2 KI and Tfr2 KO), and with normal or increased iron availability [57]. The evaluations were performed in bone marrow and spleen, in young and adult animals to unravel the erythropoietic role of Tfr2 isoforms at different ages, and in the two main erythropoietic organs. It resulted that the lack of Tfr2 in Tfr2 $\mathrm{KO}$ mice leads to macrocytosis with low reticulocyte number and increased $\mathrm{Hb}$ value, together with an anticipation of erythropoiesis in young mice both in BM and in the spleen [71], probably because the increased systemic iron amount present in these animals allows them to reach mature erythropoiesis even at a young age.

Although different animals and approaches were used in these studies, and partially contradictory results were obtained, they all demonstrate that erythropoiesis is impaired by a lack of Tfr2 in BM, independently from its activity in hepatic tissues.

Moreover, results obtained studying Tfr2 KI $\left(\alpha^{+} \beta^{0}\right)$ mice [57] demonstrated, for the first time, the involvement of Tfr $2 \beta$ in favoring iron availability for erythropoiesis. In fact, the sole lack of Tfr $2 \beta$, in normal systemic iron condition, causes an increased but immature splenic erythropoiesis seen only in young mice, as if they had insufficient iron availability during animal growth, that is normalized in animal adult age. Decreased iron availability for erythropoiesis in Tfr2 KI young mice is demonstrated by increased ferritin $(\mathrm{Ft})$ and decreased divalent metals transporter 1 (DMT1) in their splenic monocyte, the increase of Erfe transcription in BM and spleen, and the low hepatic Hepc transcription that could, in turn, be responsible for the increased splenic Fpn1 amount in these animals [71].

This effect, due to Tfr $2 \beta$ absence, in aged matched Tfr $2 \mathrm{KO}\left(\alpha^{0} \beta^{0}\right)$ mice, was compensated by the increased amount of circulating iron available that may be used for erythrocyte production (Figure $3 \mathrm{~A}$ ). 
A

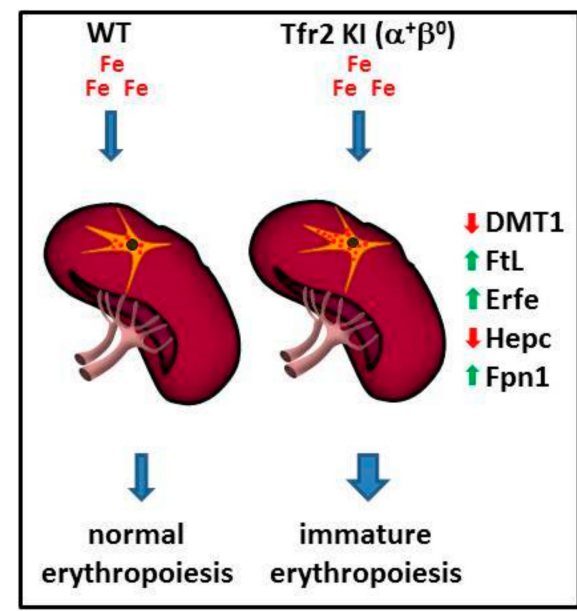

B

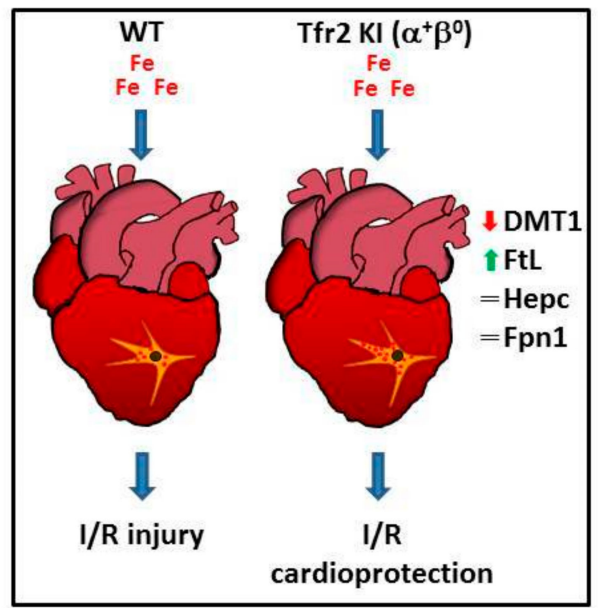

Figure 3. Schematic model illustrating Tfr $2 \beta$ function in regulation iron export from reticulo-endothelial (REL) cells. Lack of Tfr2 $\beta$ causes an increased iron retention in REL cells that (A) causes the onset of an immature erythropoiesis in the spleen, and (B) induces a cardioprotection against the effect of the reperfusion of oxygenated solutions after an ischemic event in heart (see text).

\subsection{Tfr $2 \beta$ in the Heart}

The cardiac muscle is a major site of oxygen consumption, so an adequate intracellular iron pool is essential to its aerobic activity. This is demonstrated by the finding that deletion of cardiac Tfr1 in mice causes fatal energetic failure in cardiomyocytes [72]. Cardiomyocytes express relatively high levels of Hepc and Fpn1, despite the fact that these cells have no role in systemic iron control [73].

Studies on mouse models demonstrated that the cardiac Hepc/Fpn1 axis is essential for heart cells' autonomous control of the intracellular iron pool that guarantees a normal cardiac functionality [73], and that Hepc/Fpn1 appears to protect the heart from the effects of systemic iron deficiency [74].

On the other side, cardiomyocytes are particularly susceptible to ROS-mediated damage because they are rich in mitochondria and consume large amounts of oxygen [75]. Therefore, when labile iron pool (LIP) expansion occurs, oxidative stress can affect cardiac functions, as it happens in severe juvenile HHC forms [10].

Although ubiquitously expressed, Tfr2 $\beta$ is highly transcribed in heart [2], such that a role for Tfr $2 \beta$ isoform in cardiac iron management has been postulated.

Indeed, in the hearts of two Tfr2 $\beta$ null mice with normal or increased systemic iron amount, Tfr2 KI and Tfr2 LCKO [57], the silencing of Tfr2 $\beta$ induces a selective activation of different proteins involved in cell survival, antioxidant enzymes, and kinases involved in cardioprotective pathways that are usually activated by stressful stimuli.

In particular, Tfr2 KI and Tfr2 LCKO mice develop a greater resistance against acute ischemia/reperfusion (I/R) challenge, irrespective of animals' systemic iron content, via the activation of the RISK or SAFE/GSK3 $\beta$ cardioprotective pathways, respectively. The iron imbalance present in these mice hearts was demonstrated by the finding that both models present the activation of antioxidant proteins, pro-apoptotic markers, and catalase, even before I/R [76]. They also have a slightly increased synthesis of cardiac ferritins, similarly to what happens in ischemic preconditioning, in which a small increase of ferritin protects cardiac cells from iron-mediated oxidative damage associated with ischemia/reperfusion injury [77].

Since previous data demonstrated a significant decrease of Fpn1, and an increased iron deposit in splenic macrophages in Tfr $2 \beta$-null mice [57,71], one might hypothesize that Tfr $2 \beta$ isoform inactivation, in the heart, causes an iron retention in cardiac reticuloendothelial cells that is able to induce cardioprotective pathways activation and to reduce iron availability to form free oxygen radicals during the reperfusion phase (Figure 3B). 


\subsection{Tfr2 in the Central Nervous System (CNS)}

Iron levels in the brain vary during life. The iron amount increases with aging in the striatum and the brain stem [78] and it is present in most CNS cell types: neurons, oligodendrocytes, microglia, and astrocytes [79]. A well-regulated iron homeostasis is important for brain development and function. Iron deficiency negatively impacts neurodevelopmental processes [80], and is also implicated in a number of psychiatric and neurological conditions, learning disabilities, attention deficit hyperactivity disorder (ADHD), and pediatric restless legs syndrome (RLS) [81,82]. On the contrary, brain iron overload is present in Alzheimer's and Huntington's neurodegenerative disorders, as well as in Parkinson's disease (PD) [83]. Nevertheless, the exact role of iron in these diseases' onset/worsening is still debated, and it remains to be clarified whether brain iron overload is directly involved in their pathogenesis, or it is a secondary effect that contributes to their clinical symptoms' progression.

The main sites of brain iron uptake are the brain vascular endothelial cells (BVECs) present in the blood-brain barrier (BBB) [84]. As in other organs, there are two main pathways responsible for CNS cells' iron uptake, the Tf-Tfr1 pathway, and the NTBI transport pathway. Traditionally, Tf-Tfr1 is considered a major pathway, and works as in all the other cell types of the organism, through a receptor-mediated endocytosis of plasma Tf circulating in the ventricles [85].

The NTBI transport pathway has been recently revaluated as a significant way to introduce iron in CNS, and it could be done through vesicular or non-vesicular mechanism. In the first case, Tf homologues, such as lactoferrin and melanotransferrin, might be involved in Tfr-mediated iron transport; moreover, the newly characterized Ft receptors, Tim 2 and Scara5, can introduce iron inside the cells through a Ft-FtR pathway. Non-vesicular iron uptake can be exerted by iron importer DMT1, that is present in endothelial cells of the brain microvasculature, as well as other importers like IN4/5/6 [86].

In CNS, the iron exporter Fpn1 is found in BVECs, neurons, oligodendrocytes, astrocytes, the choroid plexus, and ependymal cells and microglia, together with ceruloplasmin $(\mathrm{CP})$ or hephaestin (Hp), the two ferroxidases that cooperate with Fpn1 to facilitate iron export [87]. Fpn1 could be the main protein responsible for iron release from CNS cells, even if other proteins and mechanisms have been brought into play for these processes [86].

Inside brain cells, the majority of iron is bound to ferritin heteropolymers ( $\mathrm{Ft} \mathrm{H} / \mathrm{L}$ ) [88]. Their cellular distribution and ratio varies with iron status, age, and disease conditions [89].

CNS iron homeostasis is intracellularly modulated by (IRE/IRPs) system [90], and by local and systemic Hepc. Injection of Hepc into the mouse lateral cerebral ventricle decreases Fpn1 protein levels and treatment of primary cultured rat neurons with Hepc decreases Fpn1 expression and reduces these cells release of iron [91]. More recently, it was demonstrated that injection of adenovirus expressing Hepc (ad-hepcidin) in brain ventricles reduces brain iron in iron-overloaded rats through the downregulation of iron transporter [92]. This data indicates that Hepc/Fpn1 axis is present and acts in CNS, as in the other districts of the organism.

It remains a matter of debate whether Hepc acting in brain is locally produced or comes from the systemic circulation crossing the BBB or both [93].

Similar to other Hepc regulatory proteins, Tfr2 gene expression has been shown in total brain extracts [2,94], in brain tumor cell lines [95], or in specific neuronal subtypes as dopaminergic neurons [3]. Furthermore, a transcriptome study on Tfr2-null mice revealed that several genes involved in the control of neuronal functions are abnormally transcribed [96]. Of note, the same experimental approaches, applied to Hfe-null mice, revealed that a consistent percentage of transcripts are modified in the same way in the two models [96]. This highlights the possibility of a cooperation between Tfr2 $\alpha$ and Hfe protein in CNS iron regulation, as in the rest of the organism.

Immunofluorescence studies using a Tfr $2 \alpha$-specific antibody demonstrate that the protein is significantly produced in mouse hippocampus, amygdala, central nucleus, and in the hypothalamic paraventricular nucleus [97]. 
A recent study assessed the situation of iron in the brain of Tfr2 $\mathrm{KO}$ mouse model vs WT sib pairs subjected to an iron-enriched diet (IED). They both are iron overloaded animals, so one could distinguish the effects of Tfr2 silencing from those due to Tfr2-independent iron load modifications.

It has been demonstrated that Tfr2 causes a lack of brain Hepc response to the systemic rise of iron levels, with altered iron mobilization and/or cellular distribution in the nervous tissue [98].

Moreover, Tfr2 KO mice present a selective over activation of neurons in the limbic circuit and the emergence of an anxious-like behavior.

Also, microglial cells showed sensitivity to iron perturbations of Tfr2 $\mathrm{KO}$ mice, being more reactive, dystrophic, and with a high level of apoptosis [97]. In light of these data, Tfr2 appears to be a key regulator of brain iron homeostasis, and could have a role in the regulation of the brain regions that are involved in the anxiety onset, mainly, the basolateral and central nucleus subregions of the amygdala [98].

\section{Tfr2 in Intracellular Iron Trafficking}

It is still under debate if Tfr $2 \alpha$ contributes to iron introduction inside the cells. When the protein was characterized, it was reported that, in vitro, it was able to introduce iron inside cells [2], but its contribution to intracellular iron amount in vivo seems to be quite negligible, since Tfr1-deficient mice present severe iron deficiency not compensated by the presence of Tfr2 [1].

Conversely, Tfr $2 \alpha$ seems to have a role in intracellular iron trafficking, at least in specific cell types. The first evidence about it was found in dopaminergic neurons, where a novel Tf/Tfr $2 \alpha$-mediated iron transport pathway to the mitochondria has been reported [3]. Disruption of this $\operatorname{Tf} / \operatorname{TfR} 2 \alpha$-dependent system has been associated with PD, and this finding highlights the role of iron accumulation in this movement disorder [3]. In this regard, a protective association between some $\operatorname{Tf}$ and $\operatorname{TfR} 2 \alpha$ genetic haplotypes and $\mathrm{PD}$ was reported, suggesting that $\mathrm{Tf}$ or a $\mathrm{Tf} / \mathrm{TfR} 2 \alpha$ complex may play a role in the etiology of these disorders [99].

More recently, a similar TfR $2 \alpha$ function in iron delivery to mitochondria has been convincingly demonstrated in erythroid cells. In an intermediate stage of human erythroid cell maturation, Tfr $2 \alpha$ was present in cytoplasmic multi-organellar complexes, formed by lysosomes surrounded by mitochondria, and found to be co-regulated with several proteins, among which, ionic channels and proteins involved in lysosomal modification and in mitochondrial membrane contacts to other intracellular organelles [100]. Therefore, Tfr2 $\alpha$ in lysosomes has been proposed to be involved in iron delivery from these organelles to mitochondria, for $\mathrm{Hb}$ synthesis. Considering the abovementioned evidence about a specific role for Tfr $2 \alpha$ in erythropoiesis, this data might represent one of the molecular processes at the basis of Tfr $2 \alpha$ erythropoietic function/s (Figure 4).

In light of the above data, Tfr $2 \alpha$ involvement in iron delivery to the mitochondria, notably, seems to work at least in the two compartments in which this protein is significantly produced: brain and bone marrow. Although a similar mechanism has been evidenced also in cell lines derived from other organs (HeLa and hepatoma cell lines) [52,101], it remains an open question if this TfR2 $\alpha$ function is present also in other cell types. 


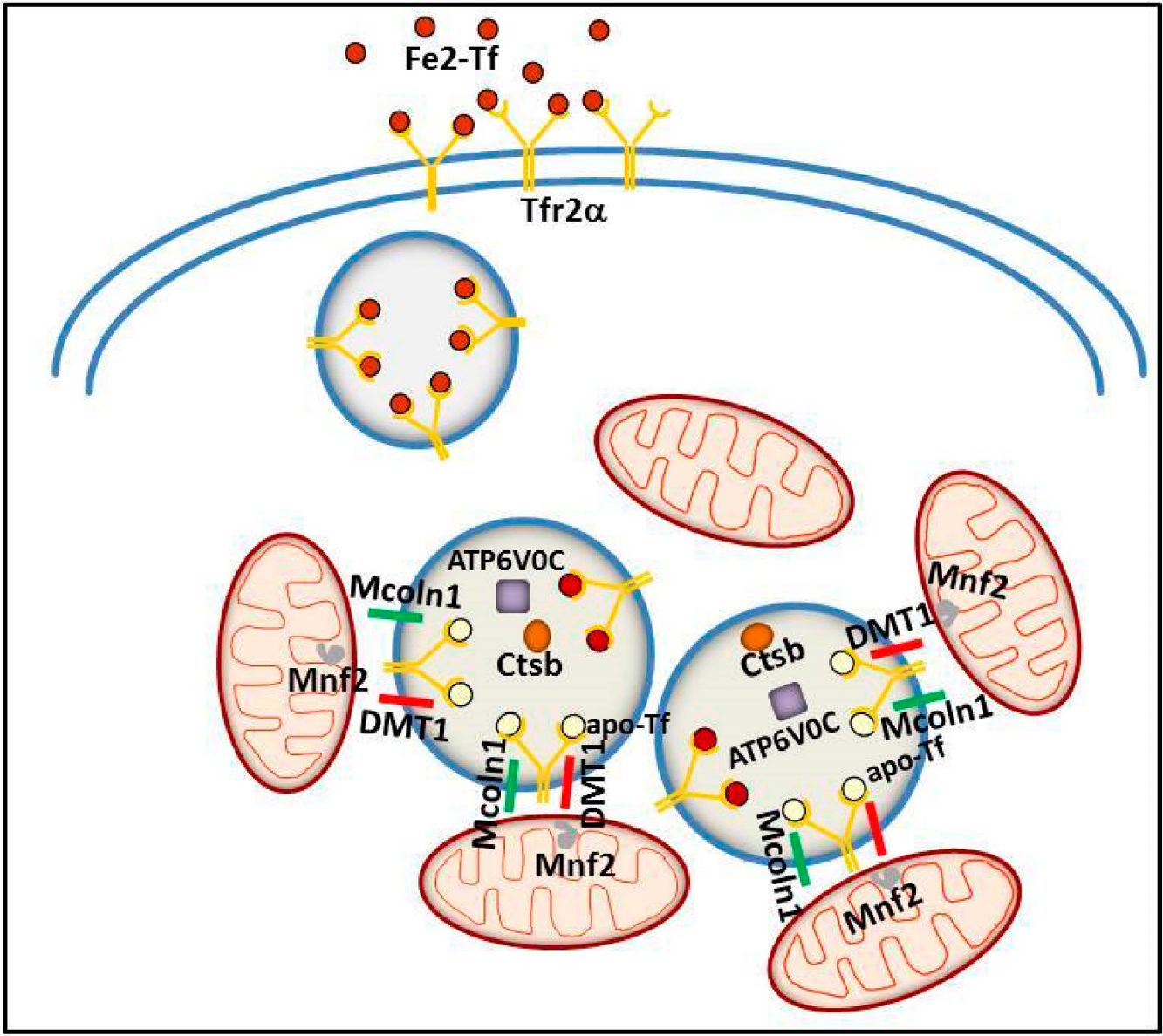

Figure 4. Schematic model illustrating the putative intracellular Tfr $2 \alpha$ role in erythroid cells. Tfr $2 \alpha$ - together with ATPV0C, a V-ATPase that contributes to vesicular acidification and lysosomal activity; Mcoln1, a lysosomal divalent cation channel; lysosomal cathepsin B (CTSB); and iron importer DMT1 - could be involved in iron delivery from lysosome to mitochondria, with the collaboration of Mitofusin-2 (MFN-2), a mitochondrial outer membrane protein involved in mitochondria-endoplasmic reticulum contacts.

\section{Tfr2 in Other Diseases}

Being a "regulator of the iron regulator" hepcidin, Tfr2 transcriptional analysis was attempted to unravel if the Tfr2 isoforms could be reliable markers for some disorders in which iron perturbations occur.

\subsection{Tfr2 in Cancer}

Cancer cells need an increased amount of iron for their growth, and iron importers upmodulation confer a selective advantage to these cells.

Since its characterization, the significant transcription of TFR2 gene appeared evident in BM cancer cells, in particular, erythroid leukemic cells [5], but also in myeloid malignant cells [2], while $\operatorname{Tfr} 2 \beta$ seemed much more prevalent than the TfR $2 \alpha$ isoform in chronic B cells lymphocytic leukemia (B-CLL) cells [102].

Due to high TFR2 expression in erythroid lineage, and to its functional relationship with the erythropoietin receptor (EpoR) [68], TFR2 transcription was evaluated in patients with myelodysplastic syndromes (MDS), a hematopoietic disorder with a variable risk to evolve in acute myeloid leukemia (AML), and in which chronic anemia can be corrected by Epo injection [103]. It has been found that Tfr2 $\alpha$ and Tfr2 $\beta$ isoforms, as well as EPOR transcript, have a lower level of transcription in BM from high risk MDS patients, such as RAEB2, compared to controls and low risk MDS cells [104]. Likewise, 
AML patients with high level of Tfr $2 \alpha$ and Tfr2 $\beta$ present an increased survival [105]. Therefore, Tfr2 isoforms might represent good predictive markers for MDS/AML prognosis.

Calzolari et al. 2007 [106] demonstrated TFR2 expression in colon and ovarian cancer cell lines, as well as in lymphoma and glioblastoma (GBM). Moreover, in glioblastoma TB10 cell line under hypoxic condition, a marked increase of TFR 2 transcription was observed. In these cell lines, TFR2 high expression is probably correlated with cell proliferation, since Tfr2 silencing inhibited GMB cell growth. Surprisingly, tumor cells from GBM patients with high TFR2 transcriptional levels present a better prognosis compared to patients with low transcripts. Although, this is probably due to the fact that Tfr2-expressing cells have a highly increased proliferation, so they are more sensitive to temozolomide, the anti-proliferative drug used in GBM therapy, more than to a direct involvement of Tfr2 in the disease course [107].

\subsection{Tfr2 in Alzheimer's Disease (AD)}

Alzheimer's disease (AD) is another common degenerative disorder in which iron perturbation has been demonstrated [108].

A recent genetic study from $116 \mathrm{AD}$ patients has found that a Tfr2 single nucleotide polymorphism (rs 7385804) and a Tfr2 haplotype, composed by two SNPs (rs 7385804 and rs 4434553) are associated with a decreased AD susceptibility [109].

In the same study, a significant decrease of Tfr2 transcription was found in peripheral blood mononuclear cells (PBMC) from AD patients, compared to healthy controls $(p<0.001)$ [110].

\section{Tfr2 as a Therapeutic Target}

In our opinion, three might be the major application of $\operatorname{Tfr} 2 \alpha$ as a therapeutic target: (a) as Hepc regulator, it could be a target in disorders in which Hepc amount is, in some way, inadequate to body iron availability; (b) since Tfr $2 \alpha$ production is selective in specific organs and cell types, it could represent a selective target to correct iron perturbation in these organs; (c) Tfr2, being a membrane protein that is able to bind plasma Tf and to be internalized with it, this property could be utilized as a vector for drugs.

As mentioned above, TfR $2 \alpha$ is involved in regulation of Hepc and, in consequence, in iron modulation according to body/organs needs. Among the Hepc-related disorders there are all the hereditary hemochromatosis forms (Table 1) and the secondary iron overload disorders, like hemoglobinopathy, where abnormally low Hepc amounts lead to iron overload.

In this regard, just published data demonstrate that Tfr2 $\mathrm{KO} \mathrm{BM}$ transplantation in beta-thalassemia intermedia ( $\beta$-TI) mouse models significantly improved these animals' erythropoiesis, opening a new way to the therapy of this very common disorder [111].

In IRIDA and anemia of chronic disease (ACD), where abnormally high Hepc causes the onset of an iron deficiency condition [111], Tfr2 downmodulation might be beneficial to decrease Hepc hyperproduction. A preliminary study on mice revealed that Tfr2 silencing, through small interfering RNAs (Tfr2-siRNA) in a single dose, led to a significant Hepc downmodulation, and increased transferrin saturation within $24 \mathrm{~h}$ post-administration, persisting for more than two weeks, and to a recovery from anemia in animal models of ACD [112].

Beside the liver, in brain, Tfr2 regulates the production of local Hepc and iron amount in the CNS, since Tfr2 KO mice brain have a blunted Hepc response to brain iron overload [97]. In recent time, it has emerged that brain Hepc production is altered in several neurodegenerative disorders: downmodulated in Alzheimer's and Parkinson's disease $[113,114]$ and upmodulated in restless legs syndrome (RLS) [115]. It might be worthwhile to further investigate if Tfr2 is involved in these Hepc variations, and consider using anti Tfr2 antibodies or siRNA-based therapy to rescue Hepc physiologic values in RLS. Nowadays, siRNA delivery to brain is quite difficult, due to the presence of the BBB, but the ongoing studies on nanoparticles' use, to target siRNA in specific sites, could allow an increase in the efficacy of this therapy [116]. 
An alternative therapeutic approach aims to deliver blocking antibody in the brain, exploiting the BBB physiologic activities. This is based on the use of anti-Tfr1 antibodies, since Tfr1 is well expressed in BBB endothelial cells and is involved in receptor-mediated transcytosis. Indeed, it has been demonstrated that the bispecific Tfr1/BACE1 ( $\beta$-amyloid cleaving enzyme-1) antibody resulted in being effective in decreasing $\beta$-amyloid concentration in the brain [117].

Due to high Tfr1/Tfr2 homology and the common cellular internalization through a receptor-mediated endocytosis pathway, one could hypothesize a parallel Tfr2-based approach for CNS, blocking antibody delivery. Nevertheless, it should be further confirmed, the presence of Tfr2 on BBB endothelial cells and its involvement in transcytosis.

Recent studies have aimed at exploiting the Tfr1 as a vehicle for drug delivery inside the cells through endocytosis, often utilizing Tfr1 natural ligand, Tf, conjugated with different synthetic molecules [1]. Moreover, since Tfr1 is able to bind and internalize FtH also [118], FtH nanocages conjugated with a PARP inhibitor, olaparib, were developed for breast cancer therapy [119].

Due to its strict homology to Tfr1, one might hypothesize that Tfr $2 \alpha$ could also be utilized to deliver drugs inside cells. This approach would be particularly useful for two main Tfr $2 \alpha$ features; Tfr $2 \alpha$-selective expression in particular tissues (hepatic, erythroid, and in CNS) and Tfr2 $\alpha$ high expression in several tumor cells, sometimes with Tfr1 and sometimes without it. High expression of Tfr 1 and Tfr $2 \alpha$ were, in fact, detected in tumor and para-cancerous normal liver tissues collected from 41 patients with hepatocellular carcinoma (HCC) [120]. Tfr2 $\alpha$ is also highly expressed in brain tumor cells in several cases of anaplastic astrocytoma and glioblastoma, but not in normal brain or endothelial brain cells [121].

Furthermore, in the light of the new data on Tfr $2 \alpha$ function in delivery iron to mitochondria, Tfr $2 \alpha$ could, possibly, represent a good vehicle for drug delivery in these organelles [122], paving the way to tailored therapies for mitochondrial iron disorders, notably Friedreich's ataxia [123].

Unfortunately, too few functional data are available at the moment on Tfr $2 \beta$ isoform to foresee possible therapeutic applications.

\section{Conclusions}

The process of body iron homeostasis is complex, and since there is no apparent significant excretory pathway, the amount of iron absorbed from mature duodenal enterocytes and that is recycled by macrophages needs to be tightly regulated. From the last decades, iron pathways have been enriched of new regulatory proteins whose functions remains to be elucidated from the molecular point of view. Each of them could represent a potential target for a focused pharmacological therapy of disorders with iron unbalance, that still represents the most prevalent of diseases all around the world.

Author Contributions: A.R. wrote the manuscript, M.M. and R.M.P. significantly contributed to the paper conceptualization, data curation, original draft preparation, review \& editing.

Funding: The APC was funded by project ROEA_RILO_18_01.

Acknowledgments: We would like to acknowledge Marco De Gobbi, Paolo Porporato, Myriam Hsu, and Delia Galeno for their help in manuscript editing.

Conflicts of Interest: The authors declare no conflict of interest.

\section{References}

1. Kawabata, H. Transferrin and transferrin receptors update. Free Radic. Biol. Med. 2018. [CrossRef] [PubMed]

2. Kawabata, H.; Yang, R.; Hirama, T.; Vuong, P.T.; Kawano, S.; Gombart, A.F.; Koeffler, H.P. Molecular cloning of transferrin receptor 2. A new member of the transferrin receptor-like family. J. Biol. Chem. 1999, 274, 20826-20832. [CrossRef] [PubMed] 
3. Mastroberardino, P.G.; Hoffman, E.K.; Horowitz, M.P.; Betarbet, R.; Taylor, G.; Cheng, D.; Na, H.M.; Gutekunst, C.A.; Gearing, M.; Trojanowski, J.Q.; et al. A novel transferrin/TfR2-mediated mitochondrial iron transport system is disrupted in Parkinson's disease. Neurobiol. Dis. 2009, 34, 417-431. [CrossRef] [PubMed]

4. Pagani, A.; Vieillevoye, M.; Nai, A.; Rausa, M.; Ladli, M.; Lacombe, C.; Mayeux, P.; Verdier, F.; Camaschella, C.; Silvestri, L. Regulation of cell surface transferrin receptor-2 by iron-dependent cleavage and release of a soluble form. Haematologica 2015, 100, 458-465. [CrossRef] [PubMed]

5. Kawabata, H.; Germain, R.S.; Ikezoe, T.; Tong, X.; Green, E.M.; Gombart, A.F.; Koeffler, H.P. Regulation of expression of murine transferrin receptor 2. Blood 2001, 98, 1949-1954. [CrossRef] [PubMed]

6. Matsuo, S.; Ogawa, M.; Muckenthaler, M.U.; Mizui, Y.; Sasaki, S.; Fujimura, T.; Takizawa, M.; Ariga, N.; Ozaki, H.; Sakaguchi, M.; et al. Hepatocyte Nuclear Factor $4 \alpha$ controls iron metabolism and regulates transferrin receptor 2 in mouse liver. J. Biol. Chem. 2015, 290, 30855-30865. [CrossRef] [PubMed]

7. Muckenthaler, M.U.; Galy, B.; Hentze, M.W. Systemic iron homeostasis and the iron-responsive element/iron-regulatory protein (IRE/IRP) regulatory network. Annu. Rev. Nutr. 2008, 28, $197-213$. [CrossRef] [PubMed]

8. Chen, J.; Enns, C.A. CD81 promotes both the degradation of transferrin receptor 2 (TfR2) and the Tfr2-mediated maintenance of hepcidin expression. J. Biol. Chem. 2015, 290, 7841-7850. [CrossRef] [PubMed]

9. Camaschella, C.; Roetto, A.; Calì, A.; De Gobbi, M.; Garozzo, G.; Carella, M.; Majorano, N.; Totaro, A.; Gasparini, P. The gene TFR2 is mutated in a new type of haemochromatosis mapping to 7q22. Nat. Genet. 2000, 25, 14-15. [CrossRef] [PubMed]

10. Brissot, P.; Cavey, T.; Ropert, M.; Guggenbuhl, P.; Loréal, O. Genetic hemochromatosis: Pathophysiology; diagnostic and therapeutic management. Presse Med. 2017, 46, e288-e295. [CrossRef] [PubMed]

11. De Gobbi, M.; Roetto, A. TFR2-Related Hereditary Hemochromatosis. In GeneReviews ${ }^{\circledR}$; Adam, M.P., Ardinger, H.H., Pagon, R.A., Wallace, S.E., Bean, L.J.H., Stephens, K., Amemiya, A., Eds.; University of Washington: Seattle, WA, USA, 2005; pp. 1993-2018.

12. Biasiotto, G.; Belloli, S.; Ruggeri, G.; Zanella, I.; Gerardi, G.; Corrado, M.; Gobbi, E.; Albertini, A.; Arosio, P. Identification of new mutations of the HFE, hepcidin, and transferrin receptor 2 genes by denaturing HPLC analysis of individuals with biochemical indications of iron overload. Clin. Chem. 2003, 49, 1981-1988. [CrossRef] [PubMed]

13. Roetto, A.; Totaro, A.; Piperno, A.; Piga, A.; Longo, F.; Garozzo, G.; Calì, A.; De Gobbi, M.; Gasparini, P.; Camaschella, C. New mutations inactivating transferrin receptor 2 in hemochromatosis type 3. Blood 2001, 97, 2555-2560. [CrossRef] [PubMed]

14. Bardou-Jacquet, E.; Cunat, S.; Beaumont-Epinette, M.P.; Kannengiesser, C.; Causse, X.; Sauvion, S.; Pouliquen, B.; Deugnier, Y.; David, V.; Loréal, O.; et al. Variable age of onset and clinical severity in transferrin receptor 2 related haemochromatosis: Novel observations. Br. J. Haematol. 2013, 162, $278-281$. [CrossRef] [PubMed]

15. Majore, S.; Milano, F.; Binni, F.; Stuppia, L.; Cerrone, A.; Tafuri, A.; De Bernardo, C.; Palka, G.; Grammatico, P. Homozygous p.M172K mutation of the TFR2 gene in an Italian family with type 3 hereditary hemochromatosis and early onset iron overload. Haematologica 2006, 91, ECR33. [PubMed]

16. Finberg, K.E. Regulation of systemic iron homeostasis. Curr. Opin. Hematol. 2013, 20, 208-214. [CrossRef] [PubMed]

17. Hunter, H.N.; Fulton, D.B.; Ganz, T.; Vogel, H.J. The solution structure of human hepcidin; a peptide hormone with antimicrobial activity that is involved in iron uptake and hereditary hemochromatosis. J. Biol. Chem. 2002, 277, 37597-37603. [CrossRef] [PubMed]

18. Ganz, T.; Nemeth, E. Hepcidin and iron homeostasis. Biochim. Biophys. Acta 2012, 1823, 1434-1443. [CrossRef] [PubMed]

19. Courselaud, B.; Pigeon, C.; Inoue, Y.; Inoue, J.; Gonzalez, F.J.; Leroyer, P.; Gilot, D.; Boudjema, K.; Guguen-Guillouzo, C.; Brissot, P.; et al. C/EBPalpha regulates hepatic transcription of hepcidin;an antimicrobial peptide and regulator of iron metabolism. Cross-talk between C/EBP pathway and iron metabolism. J. Biol. Chem. 2002, 277, 41163-41170. [CrossRef] [PubMed]

20. Canali, S.; Zumbrennen-Bullough, K.B.; Core, A.B.; Wang, C.Y.; Nairz, M.; Bouley, R.; Swirski, F.K.; Babitt, J.L. Endothelial cells produce bone morphogenetic protein 6 required for iron homeostasis in mice. Blood 2017, 129, 405-414. [CrossRef] [PubMed] 
21. Steinbicker, A.U.; Bartnikas, T.B.; Lohmeyer, L.K.; Leyton, P.; Mayeur, C.; Kao, S.M.; Pappas, A.E.; Peterson, R.T.; Bloch, D.B.; Yu, P.B.; et al. Perturbation of hepcidin expression by BMP type I receptor deletion induces iron overload in mice. Blood 2011, 118, 4224-4230. [CrossRef] [PubMed]

22. Mayeur, C.; Leyton, P.A.; Kolodziej, S.A.; Yu, B.; Bloch, K.D. BMP type II receptors have redundant roles in the regulation of hepatic hepcidin gene expression and iron metabolism. Blood 2014, 124, 2116-2123. [CrossRef] [PubMed]

23. Enns, C.A.; Ahmed, R.; Zhang, A.S. Neogenin interacts with matriptase-2 to facilitate hemojuvelin cleavage. J. Biol. Chem. 2012, 287, 35104-35117. [CrossRef] [PubMed]

24. Canali, S.; Wang, C.Y.; Zumbrennen-Bullough, K.B.; Bayer, A.; Babitt, J.L. Bone morphogenetic protein 2 controls iron homeostasis in mice independent of Bmp6. Am. J. Hematol. 2017, 92, 1204-1213. [CrossRef] [PubMed]

25. Schmidt, P.J.; Toran, P.T.; Giannetti, A.M.; Bjorkman, P.J.; Andrews, N.C. The transferrin receptor modulates Hfe-dependent regulation of hepcidin expression. Cell Metab. 2008, 7, 205-214. [CrossRef] [PubMed]

26. Gao, J.; Chen, J.; Kramer, M.; Tsukamoto, H.; Zhang, A.S.; Enns, C.A. Interaction of the hereditary hemochromatosis protein HFE with transferrin receptor 2 is required for transferrin-induced hepcidin expression. Cell Metab. 2009, 9, 217-227. [CrossRef] [PubMed]

27. D'Alessio, F.; Hentze, M.; Muckenthaler, M.U. The hemochromatosis proteins HFE; TfR2; and HJV form a membrane-associated protein complex for hepcidin regulation. J. Hepatol. 2012, 57, 1052-1060. [CrossRef] [PubMed]

28. Wallace, D.F.; Summerville, L.; Crampton, E.M.; Frazer, D.M.; Anderson, G.J.; Subramaniam, V.N. Combined deletion of Hfe and transferrin receptor 2 in mice leads to marked dysregulation of hepcidin and iron overload. Hepatology 2009, 50, 1992-2000. [CrossRef] [PubMed]

29. Poli, M.; Luscieti, S.; Gandini, V.; Maccarinelli, F.; Finazzi, D.; Silvestri, L.; Roetto, A.; Arosio, P. Transferrin receptor 2 and HFE regulate furin expression via mitogen-activated protein kinase/extracellular signal-regulated kinase (MAPK/Erk) signaling. Implications for transferrin- dependent hepcidin regulation. Haematologica 2010, 95, 1832-1840. [CrossRef] [PubMed]

30. Corradini, E.; Rozier, M.; Meynard, D.; Odhiambo, A.; Lin, H.Y.; Feng, Q.; Migas, M.C.; Britton, R.S.; Babitt, J.L.; Fleming, R.E. Iron regulation of hepcidin despite attenuated Smad1,5,8 signaling in mice without transferrin receptor 2 or Hfe. Gastroenterology 2011, 141, 1907-1914. [CrossRef] [PubMed]

31. Silvestri, L.; Pagani, A.; Nai, A.; De Domenico, I.; Kaplan, J.; Camaschella, C. The serine protease matriptase-2 (TMPRSS6) inhibits hepcidin activation by cleaving membrane hemojuvelin. Cell Metab. 2008, 8, 502-511. [CrossRef] [PubMed]

32. Meynard, D.; Vaja, V.; Sun, C.C.; Corradini, E.; Chen, S.; López-Otín, C.; Grgurevic, L.; Hong, C.C.; Stirnberg, M.; Gütschow, M.; et al. Regulation of TMPRSS6 by BMP6 and iron in human cells and mice. Blood 2011, 118, 747-756. [CrossRef] [PubMed]

33. Nicolas, G.; Chauvet, C.; Viatte, L.; Danan, J.L.; Bigard, X.; Devaux, I.; Beaumont, C.; Kahn, A.; Vaulont, S. The gene encoding the iron regulatory peptide hepcidin is regulated by anemia; hypoxia; and inflammation. J. Clin. Investig. 2002, 110, 1037-1044. [CrossRef] [PubMed]

34. Donovan, A.; Lima, C.A.; Pinkus, J.L.; Pinkus, G.S.; Zon, L.I.; Robine, S.; Andrews, N.C. The iron exporter ferroportin/Slc40a1 is essential for iron homeostasis. Cell Metab. 2005, 1, 191-200. [CrossRef] [PubMed]

35. Nemeth, E.; Tuttle, M.S.; Powelson, J.; Vaughn, M.B.; Donovan, A.; Ward, D.M.; Ganz, T.; Kaplan, J. Hepcidin regulates cellular iron efflux by binding to ferroportin and inducing its internalization. Science 2004, 306, 2090-2093. [CrossRef] [PubMed]

36. Papanikolaou, G.; Pantopoulos, K. Systemic iron homeostasis and erythropoiesis. IUBMB Life 2017, 69, 399-413. [CrossRef] [PubMed]

37. Wrighting, D.M.; Andrews, N.C. Interleukin-6 induces hepcidin expression through STAT3. Blood 2006, 108, 3204-3209. [CrossRef] [PubMed]

38. Armitage, A.E.; Eddowes, L.A.; Gileadi, U.; Cole, S.; Spottiswoode, N.; Selvakumar, T.A.; Ho, L.P.; Townsend, A.R.; Drakesmith, H. Hepcidin regulation by innate immune and infectious stimuli. Blood 2011, 118, 4129-4139. [CrossRef] [PubMed]

39. Piperno, A.; Galimberti, S.; Mariani, R.; Pelucchi, S.; Ravasi, G.; Lombardi, C.; Bilo, G.; Revera, M.; Giuliano, A.; Faini, A.; et al. Modulation of hepcidin production during hypoxia-induced erythropoiesis in humans in vivo: Data from the HIGHCARE project. Blood 2011, 117, 2953-2959. [CrossRef] [PubMed] 
40. Talbot, N.P.; Lakhal, S.; Smith, T.G.; Privat, C.; Nickol, A.H.; Rivera-Ch, M.; León-Velarde, F.; Dorrington, K.L.; Mole, D.R.; Robbins, P.A. Regulation of hepcidin expression at high altitude. Blood 2012, 119, 857-860. [CrossRef] [PubMed]

41. Maurer, E.; Gütschow, M.; Stirnberg, M. Matriptase-2 (TMPRSS6) is directly up-regulated by hypoxia inducible factor-1: Identification of a hypoxia-responsive element in the TMPRSS6 promoter region. Biol. Chem. 2012, 393, 535-540. [CrossRef] [PubMed]

42. Kawabata, H.; Fleming, R.E.; Gui, D.; Moon, S.Y.; Saitoh, T.; O’Kelly, J.; Umehara, Y.; Wano, Y.; Said, J.W.; Koeffler, H.P. Expression of hepcidin is down-regulated in TfR2 mutant mice manifesting a phenotype of hereditary hemochromatosis. Blood 2005, 105, 376-381. [CrossRef] [PubMed]

43. Nemeth, E.; Roetto, A.; Garozzo, G.; Ganz, T.; Camaschella, C. Hepcidin is decreased in TFR2 hemochromatosis. Blood 2005, 105, 1803-1806. [CrossRef] [PubMed]

44. Du, X.; She, E.; Gelbart, T.; Truksa, J.; Lee, P.; Xia, Y.; Khovananth, K.; Mudd, S.; Mann, N.; Moresco, E.M.; et al. The serine protease TMPRSS6 is required to sense iron deficiency. Science 2008, 320, 1088-1092. [CrossRef] [PubMed]

45. Finberg, K.E.; Heeney, M.M.; Campagna, D.R.; Aydinok, Y.; Pearson, H.A.; Hartman, K.R.; Mayo, M.M.; Samuel, S.M.; Strouse, J.J.; Markianos, K.; et al. Mutations in TMPRSS6 cause iron-refractory iron deficiency anemia (IRIDA). Nat. Genet. 2008, 40, 569-571. [CrossRef] [PubMed]

46. Folgueras, A.R.; de Lara, F.M.; Pendás, A.M.; Garabaya, C.; Rodríguez, F.; Astudillo, A.; Bernal, T.; Cabanillas, R.; López-Otín, C.; Velasco, G. Membrane-bound serine protease matriptase-2 (Tmprss6) is an essential regulator of iron homeostasis. Blood 2008, 112, 2539-2545. [CrossRef] [PubMed]

47. Calzolari, A.; Raggi, C.; Deaglio, S.; Sposi, N.M.; Stafsnes, M.; Fecchi, K.; Parolini, I.; Malavasi, F.; Peschle, C.; Sargiacomo, M.; et al. TfR2 localizes in lipid raft domains and is released in exosomes to activate signal transduction along the MAPK pathway. J. Cell Sci. 2006, 119, 4486-4498. [CrossRef] [PubMed]

48. Simons, K.; Toomre, D. Lipid rafts and signal transduction. Nat. Rev. Mol. Cell Biol. 2000, 1, 31-39. [CrossRef] [PubMed]

49. Chen, J.; Wang, J.; Meyers, K.R.; Enns, C.A. Transferrin-directed internalization and cycling of transferrin receptor 2. Traffic 2009, 10, 1488-1501. [CrossRef] [PubMed]

50. Johnson, M.B.; Enns, C.A. Diferric transferrin regulates transferrin receptor 2 protein stability. Blood 2004, 104, 4287-4293. [CrossRef] [PubMed]

51. Chen, J.; Enns, C.A. The cytoplasmic domain of transferrin receptor 2 dictates its stability and response to holo-transferrin in Hep3B cells. J. Biol. Chem. 2007, 282, 6201-6209. [CrossRef] [PubMed]

52. Johnson, M.B.; Chen, J.; Murchison, N.; Green, F.A.; Enns, C.A. Transferrin receptor 2: Evidence for ligand-induced stabilization and redirection to a recycling pathway. Mol. Biol. Cell 2007, 18, 743-754. [CrossRef] [PubMed]

53. Goswami, T.; Andrews, N.C. Hereditary hemochromatosis protein; HFE; interaction with transferrin receptor 2 suggests a molecular mechanism for mammalian iron sensing. J. Biol. Chem. 2006, 281, 28494-28498. [CrossRef] [PubMed]

54. Valore, E.V.; Ganz, T. Posttranslational processing of hepcidin in human hepatocytes is mediated by the prohormone convertase furin. Blood Cells Mol. Dis. 2008, 40, 132-138. [CrossRef] [PubMed]

55. Fleming, R.E.; Ahmann, J.R.; Migas, M.C.; Waheed, A.; Koeffler, H.P.; Kawabata, H.; Britton, R.S.; Bacon, B.R.; Sly, W.S. Targeted mutagenesis of the murine transferrin receptor-2 gene produces hemochromatosis. Proc. Natl. Acad. Sci. USA 2002, 99, 10653-10658. [CrossRef] [PubMed]

56. Wallace, D.F.; Summerville, L.; Subramaniam, V.N. Targeted disruption of the hepatic transferrin receptor 2 gene in mice leads to iron overload. Gastroenterology 2007, 132, 301-310. [CrossRef] [PubMed]

57. Roetto, A.; Di Cunto, F.; Pellegrino, R.M.; Hirsch, E.; Azzolino, O.; Bondi, A.; Defilippi, I.; Carturan, S.; Miniscalco, B.; Riondato, F.; et al. Comparison of 3 Tfr2-deficient murine models suggests distinct functions for Tfr2-alpha and Tfr2-beta isoforms in different tissues. Blood 2010, 115, 3382-3389. [CrossRef] [PubMed]

58. Fleming, R.E.; Feng, Q.; Britton, R.S. Knockout mouse models of iron homeostasis. Annu. Rev. Nutr. 2011, 31, 117-137. [CrossRef] [PubMed]

59. Gutschow, P.; Schmidt, P.J.; Han, H.; Ostland, V.; Bartnikas, T.B.; Pettiglio, M.A.; Herrera, C.; Butler, J.S.; Nemeth, E.; Ganz, T.; et al. A competitive enzyme-linked immunosorbent assay specific for murine hepcidin-1: Correlation with hepatic mRNA expression in established and novel models of dysregulated iron homeostasis. Haematologica 2015, 100, 167-177. [CrossRef] [PubMed] 
60. Latour, C.; Besson-Fournier, C.; Meynard, D.; Silvestri, L.; Gourbeyre, O.; Aguilar-Martinez, P.; Schmidt, P.J.; Fleming, M.D.; Roth, M.P.; Coppin, H. Differing impact of the deletion of hemochromatosis-associated molecules HFE and transferrin receptor- 2 on the iron phenotype of mice lacking bone morphogenetic protein 6 or hemojuvelin. Hepatology 2016, 63, 126-137. [CrossRef] [PubMed]

61. Nai, A.; Pellegrino, R.M.; Rausa, M.; Pagani, A.; Boero, M.; Silvestri, L.; Saglio, G.; Roetto, A.; Camaschella, C. The erythroid function of transferrin receptor 2 revealed by Tmprss 6 inactivation in different models of transferrin receptor 2 knockout mice. Haematologica 2014, 99, 1016-1021. [CrossRef] [PubMed]

62. Rishi, G.; Secondes, E.S.; Wallace, D.F.; Subramaniam, V.N. Hematopoietic deletion of transferrin receptor 2 in mice leads to a block in erythroid differentiation during iron-deficient anemia. Am. J. Hematol. 2016, 91, 812-818. [CrossRef] [PubMed]

63. Marro, S.; Chiabrando, D.; Messana, E.; Stolte, J.; Turco, E.; Tolosano, E.; Muckenthaler, M.U. Heme controls ferroportin1 (FPN1) transcription involving Bach1; Nrf2 and a MARE/ARE sequence motif at position -7007 of the FPN1 promoter. Haematologica 2010, 95, 1261-1268. [CrossRef] [PubMed]

64. Chiabrando, D.; Fiorito, V.; Marro, S.; Silengo, L.; Altruda, F.; Tolosano, E. Cell-specific regulation of Ferroportin transcription following experimentally-induced acute anemia in mice. Blood Cells Mol. Dis. 2013, 50, 25-30. [CrossRef] [PubMed]

65. Zhang, D.L.; Hughes, R.M.; Ollivierre-Wilson, H.; Ghosh, M.C.; Rouault, T.A. A ferroportin transcript that lacks an iron-responsive element enables duodenal and erythroid precursor cells to evade translational repression. Cell Metab. 2009, 9, 461-473. [CrossRef] [PubMed]

66. Soranzo, N.; Spector, T.D.; Mangino, M.; Kühnel, B.; Rendon, A.; Teumer, A.; Willenborg, C.; Wright, B.; Chen, L.; Li, M.; et al. A genome-wide meta-analysis identifies 22 loci associated with eight hematological parameters in the HaemGen consortium. Nat. Genet. 2009, 41, 1182-1190. [CrossRef] [PubMed]

67. Auer, P.L.; Teumer, A.; Schick, U.; O'Shaughnessy, A.; Lo, K.S.; Chami, N.; Carlson, C.; de Denus, S.; Dubé, M.P.; Haessler, J.; et al. Rare and low frequency coding variants in CXCR2 and other genes are associated with hematological traits. Nat. Genet. 2014, 46, 629-634. [CrossRef] [PubMed]

68. Forejtnikovà, H.; Vieillevoye, M.; Zermati, Y.; Lambert, M.; Pellegrino, R.M.; Guihard, S.; Gaudry, M.; Camaschella, C.; Lacombe, C.; Roetto, A.; et al. Transferrin receptor 2 is a component of the erythropoietin receptor complex and is required for efficient erythropoiesis. Blood 2010, 116, 5357-5367. [CrossRef] [PubMed]

69. Nai, A.; Lidonnici, M.R.; Rausa, M.; Mandelli, G.; Pagani, A.; Silvestri, L.; Ferrari, G.; Camaschella, C. The second transferrin receptor regulates red blood cell production in mice. Blood 2015, 125, 1170-1179. [CrossRef] [PubMed]

70. Kautz, L.; Jung, G.; Valore, E.V.; Rivella, S.; Nemeth, S.; Ganz, T. Identification of erythroferrone as an erythroid regulator of iron metabolism. Nat. Genet. 2014, 46, 678-684. [CrossRef] [PubMed]

71. Pellegrino, R.M.; Riondato, F.; Ferbo, L.; Boero, M.; Palmieri, A.; Osella, L.; Pollicino, P.; Miniscalco, B.; Saglio, G.; Roetto, A. Altered Erythropoiesis in Mouse Models of Type 3 Hemochromatosis. Biomed. Res. Int. 2017, 2408941. [CrossRef] [PubMed]

72. Xu, W.; Barrientos, T.; Mao, L.; Rockman, H.A.; Sauve, A.A.; Andrews, N.C. Lethal cardiomyopathy in mice lacking transferrin receptor in the heart. Cell Rep. 2015, 13, 533-545. [CrossRef] [PubMed]

73. Lakhal-Littleton, S.; Wolna, M.; Carr, C.A.; Miller, J.J.; Christian, H.C.; Ball, V.; Santos, A.; Diaz, R.; Biggs, D.; Stillion, R.; et al. Cardiac ferroportin regulates cellular iron homeostasis and is important for cardiac function. Proc. Natl. Acad. Sci. USA 2015, 112, 3164-3169. [CrossRef] [PubMed]

74. Lakhal-Littleton, S.; Wolna, M.; Chung, Y.J.; Christian, H.C.; Heather, L.C.; Brescia, M.; Ball, V.; Diaz, R.; Santos, A.; Biggs, D.; et al. An essential cell-autonomous role for hepcidin in cardiac iron homeostasis. Elife 2016, 5, e19804. [CrossRef] [PubMed]

75. Gammella, E.; Recalcati, S.; Rybinska, I.; Buratti, P.; Cairo, G. Iron-induced damage in cardiomyopathy: Oxidative-dependent and independent mechanisms. Oxid. Med. Cell. Longev. 2015. [CrossRef] [PubMed]

76. Boero, M.; Pagliaro, P.; Tullio, F.; Pellegrino, R.M.; Palmieri, A.; Ferbo, L.; Saglio, G.; De Gobbi, M.; Penna, C.; Roetto, A. A comparative study of myocardial molecular phenotypes of two Tfr $\beta$ null mice: Role in ischemia/reperfusion. Biofactors 2015, 41, 360-371. [CrossRef] [PubMed]

77. Chevion, M.; Leibowitz, S.; Aye, N.N.; Novogrodsky, O.; Singer, A.; Avizemer, O.; Bulvik, B.; Konijn, A.M.; Berenshtein, E. Heart protection by ischemic preconditioning: A novel pathway initiated by iron and mediated by ferritin. J. Mol. Cell. Cardiol. 2008, 45, 839-845. [CrossRef] [PubMed] 
78. Aquino, D.; Bizzi, A.; Grisoli, M.; Garavaglia, B.; Bruzzone, M.G.; Nardocci, N.; Savoiardo, M.; Chiapparini, L. Age-related iron deposition in the basal ganglia: Quantitative analysis in healthy subjects. Radiology 2009, 252, 165-172. [CrossRef] [PubMed]

79. Pfefferbaum, A.; Adalsteinsson, E.; Rohlfing, T.; Sullivan, E.V. MRI estimates of brain iron concentration in normal aging: Comparison of field-dependent (FDRI) and phase (SWI) methods. Neuroimage 2009, 47, 493-500. [CrossRef] [PubMed]

80. Carlson, E.S.; Fretham, S.J.; Unger, E.; O'Connor, M.; Petryk, A.; Schallert, T.; Rao, R.; Tkac, I.; Georgieff, M.K. Hippocampus specific iron deficiency alters competition and cooperation between developing memory systems. J. Neurodev. Disord. 2010, 2, 133-143. [CrossRef] [PubMed]

81. Millichap, J.G. Etiologic classification of attention-deficit/hyperactivity disorder. Pediatrics 2008, 12, e358-e365. [CrossRef] [PubMed]

82. Benton, D. The influence of dietary status on the cognitive performance of children. Mol. Nutr. Food Res. 2010, 54, 457-470. [CrossRef] [PubMed]

83. Xu, H.; Wang, Y.; Song, N.; Wang, J.; Jiang, H.; Xie, J. New Progress on the Role of Glia in Iron Metabolism and Iron-Induced Degeneration of Dopamine Neurons in Parkinson's Disease. Front. Mol. Neurosci. 2018, 10, 455. [CrossRef] [PubMed]

84. McCarthy, R.C.; Kosman, D.J. Mechanistic analysis of iron accumulation by endothelial cells of the BBB. Biometals 2012, 25, 665-675. [CrossRef] [PubMed]

85. Benarroch, E.E. Brain iron homeostasis and neurodegenerative disease. Neurology 2009, 72, $1436-1440$. [CrossRef] [PubMed]

86. Mills, E.; Dong, X.P.; Wang, F.; Xu, H. Mechanisms of brain iron transport: Insight into neurodegeneration and CNS disorders. Future Med. Chem. 2010, 2, 51-64. [CrossRef] [PubMed]

87. Wang, J.; Jiang, H.; Xie, J.X. Ferroportin1 and hephaestin are involved in the nigral iron accumulation of 6-OHDA-lesioned rats. Eur. J. Neurosci. 2007, 25, 2766-2772. [CrossRef] [PubMed]

88. Morris, C.M.; Candy, J.M.; Keith, A.B.; Oakley, A.E.; Taylor, G.A.; Pullen, R.G.; Bloxham, C.A.; Gocht, A.; Edwardson, J.A. Brain iron homeostasis. J. Inorg. Biochem. 1992, 47, 257-265. [CrossRef]

89. Connor, J.R.; Boeshore, K.L.; Benkovic, S.A.; Menzies, S.L. Isoforms of ferritin have a specific cellular distribution in the brain. J. Neurosci. Res. 1994, 37, 461-465. [CrossRef] [PubMed]

90. Rouault, T.A. Iron metabolism in the CNS: Implications for neurodegenerative diseases. Nat. Rev. Neurosci. 2013, 14, 551-564. [CrossRef] [PubMed]

91. Wang, S.M.; Fu, L.J.; Duan, X.L.; Crooks, D.R.; Yu, P.; Qian, Z.M.; Di, X.J.; Li, J.; Rouault, T.A.; Chang, Y.Z. Role of hepcidin in murine brain iron metabolism. Cell. Mol. Life Sci. 2010, 67, 123-133. [CrossRef] [PubMed]

92. Du, F.; Qian, Z.M.; Luo, Q.; Yung, W.H.; Ke, Y. Hepcidin suppresses brain iron accumulation by downregulating iron transport proteins in iron-overloaded rats. Mol. Neurobiol. 2015, 52, 101-114. [CrossRef] [PubMed]

93. Vela, D. Hepcidin, an emerging and important player in brain iron homeostasis. J. Transl. Med. 2018, 16. [CrossRef] [PubMed]

94. Moos, T.; Rosengren Nielsen, T.; Skjørringe, T.; Morgan, E.H. Iron trafficking inside the brain. J. Neurochem. 2007, 103, 1730-1740. [CrossRef] [PubMed]

95. Hänninen, M.M.; Haapasalo, J.; Haapasalo, H.; Fleming, R.E.; Britton, R.S.; Bacon, B.R.; Parkkila, S. Expression of iron-related genes in human brain and brain tumors. BMC Neurosci. 2009, 10, 36. [CrossRef] [PubMed]

96. Acikyol, B.; Graham, R.M.; Trinder, D.; House, M.J.; Olynyk, J.K.; Scott, R.J.; Milward, E.A.; Johnstone, D.M. Brain transcriptome perturbations in the transferrin receptor 2 mutant mouse support the case for brain changes in iron loading disorders, including effects relating to long-term depression and long-term potentiation. Neuroscience 2013, 235, 119-128. [CrossRef] [PubMed]

97. Pellegrino, R.M.; Boda, E.; Montarolo, F.; Boero, M.; Mezzanotte, M.; Saglio, G.; Buffo, A.; Roetto, A. Transferrin Receptor 2 Dependent Alterations of Brain Iron Metabolism Affect Anxiety Circuits in the Mouse. Sci. Rep. 2016, 6, 30725. [CrossRef] [PubMed]

98. Adhikari, A. Distributed circuits underlying anxiety. Front. Behav. Neurosci. 2014, 8, 112. [CrossRef] [PubMed] 
99. Rhodes, S.L.; Buchanan, D.D.; Ahmed, I.; Taylor, K.D.; Loriot, M.A.; Sinsheimer, J.S.; Bronstein, J.M.; Elbaz, A.; Mellick, G.D.; Rotter, J.I.; et al. Pooled analysis of iron-related genes in Parkinson's disease: Association with transferrin. Neurobiol. Dis. 2014, 62, 172-178. [CrossRef] [PubMed]

100. Khalil, S.; Holy, M.; Grado, S.; Fleming, R.; Kurita, R.; Nakamura, Y.; Goldfarb, A. A specialized pathway for erythroid iron delivery through lysosomal trafficking of transferrin receptor 2. Blood Adv. 2017, 1, 1181-1194. [CrossRef] [PubMed]

101. Robb, A.D.; Ericsson, M.; Wessling-Resnick, M. Transferrin receptor 2 mediates a biphasic pattern of transferrin uptake associated with ligand delivery to multivesicular bodies. Am. J. Physiol. Cell Physiol. 2004, 287, C1769-C1775. [CrossRef] [PubMed]

102. Smilevska, T.; Stamatopoulos, K.; Samara, M.; Belessi, C.; Tsompanakou, A.; Paterakis, G.; Stavroyianni, N.; Athanasiadou, I.; Chiotoglou, I.; Hadzidimitriou, A.; et al. Transferrin receptor-1 and 2 expression in chronic lymphocytic leukemia. Leuk. Res. 2006, 30, 183-189. [CrossRef] [PubMed]

103. Gangat, N.; Patnaik, M.M.; Tefferi, A. Myelodysplastic syndromes: Contemporary review and how we treat. Am. J. Hematol. 2016, 91, 76-89. [CrossRef] [PubMed]

104. Di Savino, A.; Gaidano, V.; Palmieri, A.; Crasto, F.; Volpengo, A.; Lorenzatti, R.; Scaravaglio, P.; Manello, A.; Nicoli, P.; Gottardi, E.; et al. Clinical significance of TFR2 and EPOR expression in bone marrow cells in myelodysplastic syndromes. Br. J. Haematol. 2017, 176, 491-495. [CrossRef] [PubMed]

105. Nakamaki, T.; Kawabata, H.; Saito, B.; Matsunawa, M.; Suzuki, J.; Adachi, D.; Tomoyasu, S.; Phillip Koeffler, H. Elevated levels of transferrin receptor $2 \mathrm{mRNA}$, not transferrin receptor $1 \mathrm{mRNA}$, are associated with increased survival in acute myeloid leukaemia. Br. J. Haematol. 2004, 125, 42-49. [CrossRef] [PubMed]

106. Calzolari, A.; Oliviero, I.; Deaglio, S.; Mariani, G.; Biffoni, M.; Sposi, N.M.; Malavasi, F.; Peschle, C.; Testa, U. Transferrin receptor 2 is frequently expressed in human cancer cell lines. Blood Cells Mol. Dis. 2007, 39, 82-91. [CrossRef] [PubMed]

107. Calzolari, A.; Larocca, L.M.; Deaglio, S.; Finisguerra, V.; Boe, A.; Raggi, C.; Ricci-Vitani, L.; Pierconti, F.; Malavasi, F.; De Maria, R.; et al. Transferrin receptor 2 is frequently and highly expressed in glioblastomas. Transl. Oncol. 2010, 3, 123-134. [CrossRef] [PubMed]

108. Crichton, R.R.; Dexter, D.T.; Ward, R.J. Brain iron metabolism and its perturbation in neurological diseases. J. Neural. Transm. 2011, 118, 301-314. [CrossRef] [PubMed]

109. Crespo, Â.C.; Silva, B.; Marques, L.; Marcelino, E.; Maruta, C.; Costa, S.; Timóteo, A.; Vilares, A.; Couto, F.S.; Faustino, P.; et al. Genetic and biochemical markers in patients with Alzheimer's disease support a concerted systemic iron homeostasis dysregulation. Neurobiol. Aging 2014, 35, 777-785. [CrossRef] [PubMed]

110. Artuso, I.; Lidonnici, M.R.; Altamura, S.; Mandelli, G.; Pettinato, M.; Muckenthaler, M.U.; Silvestri, L.; Ferrari, G.; Camaschella, C.; Nai, A. Transferrin Receptor 2 is a potential novel therapeutic target for beta-thalassemia: Evidence from a murine model. Blood 2018. [CrossRef] [PubMed]

111. Girelli, D.; Nemeth, E.; Swinkels, D.W. Hepcidin in the diagnosis of iron disorders. Blood 2016, 127, $2809-2813$. [CrossRef] [PubMed]

112. Akinc, A.; Chan-Daniels, A.; Sehgal, A.; Foster, D.; Bettencourt, B.R.; Hettinger, J.; Racie, T.; Aubin, J.; Kuchimanchi, S.; Epstein-Barashand, H.; et al. Targeting the hepcidin pathway with RNAi therapeutics for the treatment of anemia. Blood 2011, 21, 688.

113. Raha, A.A.; Vaishnav, R.A.; Friedland, R.P.; Bomford, A.; Raha-Chowdhury, R. The systemic iron-regulatory proteins hepcidin and ferroportin are reduced in the brain in Alzheimer's disease. Acta Neuropathol. Commun. 2013, 1, 55. [CrossRef] [PubMed]

114. Chen, D.; Kanthasamy, A.G.; Reddy, M.B. EGCG protects against 6-OHDA-induced neurotoxicity in a cell culture model. Parkinsons Dis. 2015. [CrossRef] [PubMed]

115. Clardy, S.L.; Wang, X.; Boyer, P.J.; Earley, C.J.; Allen, R.P.; Connor, J.R. Is ferroportin-hepcidin signaling altered in restless legs syndrome? J. Neurol. Sci. 2006, 247, 173-179. [CrossRef] [PubMed]

116. Zheng, M.; Tao, W.; Zou, Y.; Farokhzad, O.C.; Shi, B. Nanotechnology-Based Strategies for siRNA Brain Delivery for Disease Therapy. Trends Biotechnol. 2018, 36, 562-575. [CrossRef] [PubMed]

117. Couch, J.A.; Yu, Y.J.; Zhang, Y.; Tarrant, J.M.; Fuji, R.N.; Meilandt, W.J.; Solanoy, H.; Tong, R.K.; Hoyte, K.; Luk, W.; et al. Addressing safety liabilities of TfR bispecific antibodies that cross the blood-brain barrier. Sci. Transl. Med. 2013, 5. [CrossRef] [PubMed] 
118. Li, L.; Fang, C.J.; Ryan, J.C.; Niemi, E.C.; Lebrón, J.A.; Björkman, P.J.; Arase, H.; Torti, F.M.; Torti, S.V.; Nakamura, M.C.; et al. Binding and uptake of H-ferritin are mediated by human transferrin receptor-1. Proc. Natl. Acad. Sci. USA 2010, 107, 3505-3510. [CrossRef] [PubMed]

119. Mazzucchelli, S.; Truffi, M.; Baccarini, F.; Beretta, M.; Sorrentino, L.; Bellini, M.; Rizzuto, M.A.; Ottria, R.; Ravelli, A.; Ciuffreda, P.; et al. H-Ferritin-nanocaged olaparib: A promising choice for both BRCA-mutated and sporadic triple negative breast cancer. Sci. Rep. 2017, 7, 7505. [CrossRef] [PubMed]

120. Sakurai, K.; Sohda, T.; Ueda, S.; Tanaka, T.; Hirano, G.; Yokoyama, K.; Morihara, D.; Aanan, A.; Takeyama, Y.; Irie, M.; et al. Immunohistochemical demonstration of transferrin receptor 1 and 2 in human hepatocellular carcinoma tissue. Hepatogastroenterology 2014, 61, 426-430. [PubMed]

121. Voth, B.; Nagasawa, D.T.; Pelargos, P.E.; Chung, L.K.; Ung, N.; Gopen, Q.; Tenn, S.; Kamei, D.T.; Yang, I. Transferrin receptors and glioblastoma multiforme: Current findings and potential for treatment. J. Clin. Neurosci. 2015, 22, 1071-1076. [CrossRef] [PubMed]

122. Murphy, M.P.; Smith, R.A. Drug delivery to mitochondria: The key to mitochondrial medicine. Adv. Drug Deliv. Rev. 2000, 41, 235-250. [CrossRef]

123. Bürk, K. Friedreich Ataxia: Current status and future prospects. Cerebellum Ataxias 2017. [CrossRef] [PubMed]

(C) 2018 by the authors. Licensee MDPI, Basel, Switzerland. This article is an open access article distributed under the terms and conditions of the Creative Commons Attribution (CC BY) license (http:/ / creativecommons.org/licenses/by/4.0/). 